\title{
SMARTSTRAP ACCESSORIES UNTUK MONITORING KONDISI PASIEN COVID-19 SAAT KARANTINA MANDIRI BERBASIS INTERNET OF THING
}

Yoga Kholilul Akbar P.S ${ }^{1}$, M. Abdullah Anshori², Abdul Rasyid ${ }^{3}$

1,2 Program Studi Jaringan Telekomunikasi Digital, Jurusan Teknik Elektro, Politeknik Negeri Malang, Indonesia

${ }^{3}$ Program Teknik Telekomunikasi Digital, Jurusan Teknik Elektro, Politeknik Negeri Malang, Indonesia 1yogakholilul11@gmail.com, ${ }^{2}$ moh.abdullah@polinema.ac.id, ${ }^{3}$ irrasmt@gmail.com

\begin{abstract}
Abstrak-Dunia sedang dilanda oleh wabah pandemi Coronavirus Disease 2019 (COVID-19) pada tahun 2021 ini. Jumlah kasus Covid19 masih terus mengalami peningkatan khususnya di Indonesia sendiri, tingginya jumlah penderita Covid-19 tidak sebanding dengan jumlah tenaga kesehatan. Alat ini bertujuan membuat aksesoris sederhana yang digunakan untuk memantau kondisi pasien yang terinfeksi Covid-19 saat menjalani karantina mandiri, serta menjadi salah satu upaya untuk menerapkan social distancing. Berdasarkan hasil pengujian yang dilakukan pada 5 sampel orang sebagai pasien, pengukuran suhu menggunakan sensor infrared MLX90614 menunjukkan rata-rata error sebesar $0,12^{\circ} \mathrm{C}$ setelah dikalibrasi menggunakan digital infrared thermometer. Sedangkan pada pengukuran sensor pulsa MAX30100 setelah dikalibrasi dengan Oxymeter SO911 memiliki rata-rata error 0,52 BPM pada pengukukuran detak jantung pada pengukuran saturasi oksigen dalam darah menunjukkan rata-rata error sebesar $0,6 \%$. Untuk hasil pengujian Quality of Service (QoS) menunjukkan nilai throughput sebesar 13,840 Kbps, packet loss 0\%, rata-rata delay 124,08649 ms dan jitter 162,2 ms.
\end{abstract}

Kata kunci-Covid-19, Suhu, Detak jantung, saturasi oksigen, Quality of Service.

Abstract - The world is being hit by an outbreak of the Coronavirus Disease 2019 (COVID-19) pandemic in 2021. The number of Covid-19 cases continues to increase, especially in Indonesia itself, the number of Covid-19 sufferers is not proportional to the number of health workers. This tool aims to make simple accessories that are used to unite the conditions of patients infected with Covid-19 while undergoing independent activities, as well as being one of the efforts to implement social distancing. Based on tests conducted on 5 samples of people as patients, temperature measurements using the MLX90614 infrared sensor showed an average error of $0.12{ }^{\circ} \mathrm{C}$ after being calibrated using a digital infrared thermometer. While the measurement of the pulse sensor MAX30100 after being calibrated with Oxymeter SO911 has an average error of $0.52 \mathrm{BPM}$ in measuring heart rate in measuring oxygen saturation in the blood, showing an average error of $0.6 \%$. For the Quality of Service $(Q 0 S)$ test results, the throughput value is $13,840 \mathrm{Kbps}$, packet loss is $0 \%$, the average delay is $124,08649 \mathrm{~ms}$ and the jitter is $162.2 \mathrm{~ms}$.

Keywords - Covid-19, Temperature, Heart rate, Oxygen saturation, Quality of Service.

\section{PENDAHULUAN}

Dunia sedang dilanda oleh wabah pandemi Covid-19 pada tahun 2021, jumlah kasus Covid-19 masih terus mengalami peningkatan. Data Worldometers menunjukkan, ada 52.389.469 kasus virus corona di dunia. Dari angka itu, sebanyak 1.288.480 orang meninggal dunia, 36.648.618 orang sembuh. Penanganan penderita Covid-19 pada saat ini telah menjadi prioritas di berbagai penjuru dunia. Penanganan ini dapat berupa penanganan langsung dan juga pencegahan penyebaran virus covid-19 dari orang ke orang. Penanganan langsung dilakukan oleh tenaga kesehatan sebagai garda terdepan, sedangkan pencegahan penyebaran Covid-19 ini dapat dilakukan oleh seluruh masyarakat, yaitu dengan cara melakukan isolasi mandiri ketika terdapat gejala ataupun tanpa gejala kemudian segera menghubungi instansi layanan kesehatan.

Indonesia tidak terlepas dari pandemi COVID-19 ini. Sesuai dengan Pedoman Pencegahan Dan Pengendalian
Coronavirus Disease (Covid-19) Revisi Ke-4, yang dikeluarkan oleh Kementrian Kesehatan RI, karantina rumah (isolasi diri) diterapkan pada orang-orang dengan status OTG (Orang Tanpa Gejala), ODP (Orang Dalam Pantauan), dan PDP (Pasien Dalam Pengawasan) dengan gejala ringan [1]. Masing-masing orang memiliki respon yang berbeda terhadap Covid-19, sebagian besar orang yang terpapar virus ini akan mengalami gejala ringan maupun sedang, dan harus melakukan isolasi mandiri yang dipantau langsung oleh pihak instansi kesehatan terdekat serta akan pulih tanpa perlu dirawat di rumah sakit.

Sistem ini mempunyai kemampuan untuk mentransfer data melalui jaringan internet tanpa memerlukan interaksi manusia - manusia, atau manusia - komputer [2-4]. Selain memantau lokasi pasien Covid-19, alat ini juga dilengkapi dengan sensor suhu MLX90614 dan sensor MAX30100 untuk mengukur detak jantung dan saturasi oksigen dalam darah, sehingga kondisi pasien juga dapat dimonitor oleh 
tenaga kesehatan secara realtime tanpa harus mendatangi pasien di rumahnya/tempat karantina mandiri yang lokasinya relatif jauh. hal ini juga sebagai upaya untuk menangani wabah Covid-19 yang semakin meluas dengan menerapkan social distancing.

\section{METODE PENELITIAN}

\section{A. Perancangan sistem}

Secara sistematis cara kerja alat yang dijalankan sistem dijadikan dalam bentuk Diagram Blok ditunjukkan Gambar 1 dibawah ini.

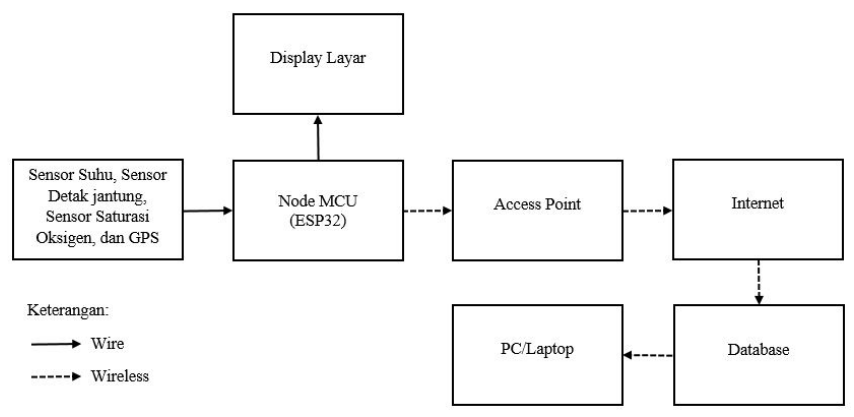

Gambar 1. Diagram Blok Sistem

Berdasarkan Gambar 1, diagram blok tahapan penelitian diatas dapat dijelaskan untuk masing-masing blok meliputi Rangkaian alat terdiri dari sensor suhu MLX90614, modul GPS Neo-6M, sensor detak jantung dan SpO2 MAX30100 serta Mikrokotroller ESP32 yang disupply dari baterai Lithium 18650 3,7V [5]. Alat digunakan untuk memonitoring kondisi pasien Covid-19 yang sedang menjalani isolasi mandiri. Alat mengukur suhu tubuh pasien, detak jantung dan saturasi oksigen dalam darah pasien. Alat juga mendeteksi titik garis lintang dan garis bujur dari suatu tempat dimana pasien berada dengan modul GPS. Data nilai kondisi kesehatan pasien dan indikator baterai akan tertampil pada display OLED. Data nilai kondisi kesehatan pasien dan lokasi pasien akan dikirimkan ke database melalui jaringan internet dan akan tertampil pada website. Database menjadi perantara antara alat yang digunakan pasien dengan website yang dioperasikan tenaga kesehatan. Database menyimpan data yang dikirim oleh mikrokontroler dan akan terus diupdate secara realtime.

Website akan mengambil data dari database dan menampilkan data berupa nilai suhu, detak jantung dalam Beats per Minute (BPM), dan saturasi oksigen dalam darah pasien yang dapat berupa angka serta lokasi koordinat pengirim berupa peta google yang di tampilkan secara realtime dari database. Apabila kondisi kesehatan pasien menurun yang ditandai dengan menurunnya parameter kesehatan pasien, maka website akan menampilkan notifikasi kepada tenaga medis setempat untuk segera dilakukan penanganan.

Berikut blok diagram input dan output perancangan sistem Smartstrap Accessories untuk Monitoring Kondisi Pasien Covid-19 Saat Karantina Mandiri Berbasis Internet of Things:

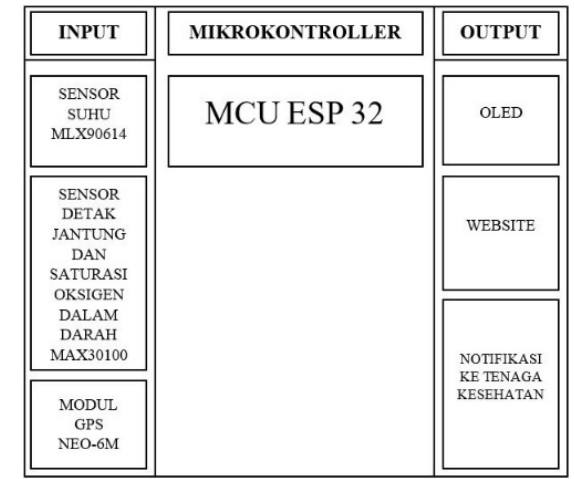

Gambar 2. Diagram Blok Perencanaan Input dan Output

Adapun penentuan prosedur yang digunakan penelitian untuk judul "Smartstrap Accessories untuk Monitoring Kondisi Pasien Covid-19 Saat Karantina Mandiri Berbasis Internet of Things" adalah sebagai berikut:

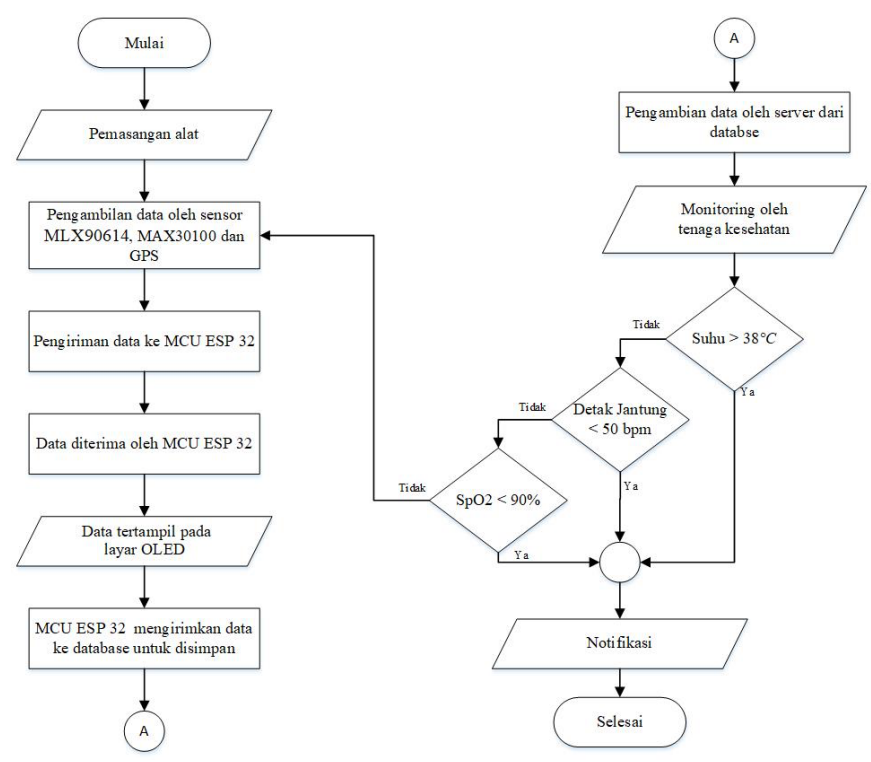

Gambar 3. Flowchart Penentuan Prosedur

Pada Gambar 3 tersebut, alat tersebut digunakan pada tubuh pasien sebagai penjepit yang menempel langsung pada jari tangan. Modul GPS Neo 6M akan mengambil titik koordinat dimana modul tersebut berada, sensor MLX90614 akan mengukur suhu tubuh pasien dan sensor MAX30100 akan mengukur detak jantung dalam Beats per Minute (BPM) dan saturasi oksigen dalam darah (SpO2) pasien Covid-19 lalu ditampilkan pada display OLED. Kemudian semua data kesehatan dan lokasi koordinat akan dikirim ke ESP32 sebagai mikrokontroler, setelah semua data diterima oleh mikrokontroler selanjutnya akan diupload ke database dan disimpan [6][7]. Server akan mengambil data dari database dan akan ditampilkan pada halaman web berupa peta digital yang hasil informasi diperoleh dari pasien berupa titik koordinat, suhu, detak jantung, dan saturasi oksigen pada darah kemudian kondisi pasien dimonitor oleh tenaga kesehatan secara realtime pada jarak jauh [8]. Pada saat tenaga kesehatan memantau kondisi pasien ketika suhu lebih dari $38^{\circ} \mathrm{C}$ atau detak jantung kurang dari $50 \mathrm{bpm}$ atau saturasi oksigen dalam darah (SpO2) kurang dari 90\% maka akan mengirim notifikasi warning pada website, hal ini sebagai awal pengingat tenaga kesehatan untuk segera mengambil tindakan pada pasien. Jika suhu, detak jantung, dan saturasi 
oksigen dalam darah terpantau normal, maka alat akan tetap terpasang pada tubuh pasien dan akan mengulangi langkahlangkah sebelumnya.

\section{HASIL DAN PEMBAHASAN}

\section{A. Pengujian sensor suhu}

Pengujian sensor suhu MLX90614 bertujuan untuk mengetahui tingkat akurasi dan error dari data hasil pengukuran sensor suhu. Dalam pengujian suhu tubuh pasien ini suhu pasien akan diukur dengan sensor suhu MLX90614 yang dibandingkan dengan alat ukur suhu digital infrared thermometer yang diletakan pada jari kemudian proses pengukur suhu dimulai. Pengamatan suhu dengan sensor akan tertampil pada layar OLED. Hasil pembacaan sensor suhu MLX90614 dan digital infrared thermometer dicatat pada tabel. Rumus perhitungan nilai error dan relative error:

Keterangan:

$$
\begin{gathered}
\text { error }=|\mathrm{Xi}-\mathrm{X}| \\
R E=\frac{|\mathrm{Xi}-\mathrm{X}|}{\mathrm{X}} \times 100 \%
\end{gathered}
$$

$\mathrm{X}=$ Data Sebenarnya

$\mathrm{Xi}=$ Data Terukur

$\mathrm{RE}=$ Relative error $\%$

Untuk menghitung kesalahan relative rata - rata atau Mean

Relative Error menggunakan rumus:

Keterangan:

$$
M R E=\frac{1}{n} \sum_{i=1}^{n} R E
$$

$\mathrm{MRE}=$ Mean Relative Error $\%$

$\mathrm{n}=$ Banyak Data

$\mathrm{RE}=$ Relative Error $\%$

TABEL 1.

HASIL PENGUJIAN SUHU SENSOR MLX90614 SETELAH KALIBRASI DENGAN THERMOMETER

\begin{tabular}{cccccc}
\hline No & Nama & $\begin{array}{c}\text { Thermometer } \\
\left({ }^{\circ} \mathbf{C}\right)\end{array}$ & $\begin{array}{c}\text { MLX90614 } \\
\left({ }^{\circ} \mathbf{C}\right)\end{array}$ & $\begin{array}{c}\text { Error } \\
\left({ }^{\circ} \mathbf{C}\right)\end{array}$ & $\begin{array}{c}\text { Relative } \\
\text { Error } \\
(\%)\end{array}$ \\
\hline 1 & Sholihin & 36,5 & 35,7 & 0,8 & 2,191 \\
2 & Adri & 37,0 & 36,6 & 0,4 & 1,081 \\
3 & Amin & 36,5 & 35,7 & 0,8 & 2,191 \\
4 & Ilman & 36,7 & 36,1 & 0,6 & 1,634 \\
5 & Fatih & 36,6 & 35,6 & 1 & 2,731 \\
\hline \multicolumn{7}{c}{ Rata - rata error dan relative error } & 0,72 & 1,966 \\
\hline
\end{tabular}

Berdasarkan tabel 1 sensor suhu MLX90614 digunakan untuk memonitoring suhu pasien telah berfungsi dengan baik akan tetapi kesalahan tingkat akurasi pengukuran sensor masih tinggi dibandingkan dengan standar alat ukur suhu, terbukti dari hasil pengujian pada sensor suhu MLX90614 didapatkan tinggkat rata-rata error sebesar $0,72^{\circ} \mathrm{C}$ yang berarti tingkat akurasi pengukuran sensor ketika dibandingkan digital infrared thermometer cukup jauh. Sehingga perlu dilakukan kalibrasi pada sensor tersebut.

Dari tabel 2 ditunjukkan bahwa dengan mengkalibrasi sensor MLX90614 tingkat akurasi sensor jauh lebih baik dari sebelumya, pada pengujian setelah dikalibrasi didapatkan nilai rata - rata error sebesar $0.12^{\circ} \mathrm{C}$. Hasil pengujian ditampilkan pada gambar 4.

TABEL 2.

HASIL PENGUJIAN SUHU SENSOR MLX90614 SETELAH KALIBRASI DENGAN THERMOMETER

\begin{tabular}{cccccc}
\hline \multirow{2}{*}{ No } & Nama & \begin{tabular}{c} 
Thermometer \\
\cline { 3 - 4 }$\left({ }^{\circ} \mathbf{C}\right)$
\end{tabular} & $\begin{array}{c}\text { MLX90614 } \\
\left({ }^{\circ} \mathbf{C}\right)\end{array}$ & $\begin{array}{c}\text { Error } \\
\left({ }^{\circ} \mathbf{C}\right)\end{array}$ & $\begin{array}{c}\text { Relative } \\
\text { Error } \\
(\%)\end{array}$ \\
\hline 1 & Sholihin & 36,5 & 36,40 & 0,1 & 0,273 \\
2 & Adri & 37,0 & 37,00 & 0 & 0 \\
3 & Amin & 36,5 & 36,4 & 0,1 & 0,273 \\
4 & Ilman & 36,7 & 36,5 & 0,2 & 0,544 \\
5 & Fatih & 36,6 & 36,40 & 0,2 & 0,546 \\
\hline \multicolumn{2}{l}{ Rata } & - rata error dan relative error & 0,12 & 0,327 \\
\hline
\end{tabular}

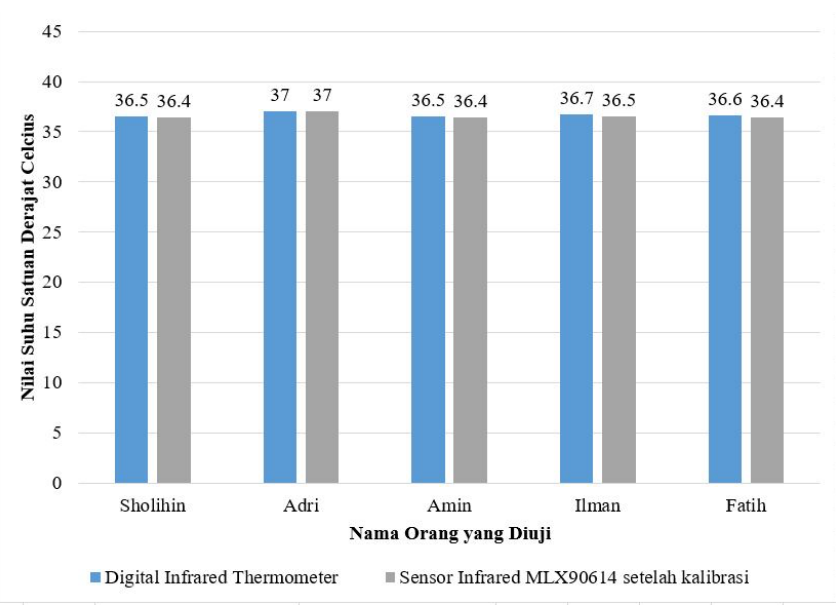

Gambar 4. Grafik perbandingan pengujian suhu tubuh menggunakan sensor MLX90164 dengan digital infrared thermometer

Dari gambar 4 Dapat dilihat hasil grafik menunjukkan perbandingan sensor suhu MLX90614 dengan digital infrared thermometer menunjukkan perbedaan yang tidak terlalu signifikan pada pengukuran sensor suhu MLX90614 yang sudah dikalibrasi. Pada salah satu sampel pasien bernama Adri merupakan sampel dengan nilai error paling kecil diantara sampel lain, menunjukkan pengukuran dengan digital infrared thermometer sebesar $37^{\circ} \mathrm{C}$ sedangkan pada sensor MLX90614 setelah dilakukan kalibrasi mendapatkan hasil $37^{\circ} \mathrm{C}$ dengan selisih error $0^{\circ} \mathrm{C}$, hasil pengukuran sensor sudah menunjukan nilai sama dengan keakuratan sensor mencapai 99,673\%.

\section{B. Pengujian sensor heart rate dan $\mathrm{SpO}_{2}$}

Pengujian yang dilakukan bertujuan untuk mengetahui tingkat akurasi dan error dari hasil pengukuran detak jantung (heart rate) dan saturasi oksigen dalam darah (SpO2) dengan memanfaatkan satu sensor yaitu MAX30100. Sensor MAX30100 akan mati setelah melakukan pengiriman pertama, oleh karena itu dalam mengukur detak jantung dan SpO2 membutuhkan 5 kali pembacaan sebelum dikirim ke database agar mendapat hasil yang sesuai dengan standar. Setelah sensor mengirim ke database, maka sensor akan direstart ulang dan mengambil data ulang sebanyak 5 kali 
kemudian dikirimkan ke database lagi, proses itu dilakukan secara terus menerus oleh sensor.

Detak jantung normal pada umumnya antara $50 \mathrm{bpm}$ sampai $100 \mathrm{bpm}$ dan untuk $\mathrm{SpO} 2$ diatas 90\%. Dalam pengujian ini sensor MAX30100 akan dibandingkan dengan alat ukur komersial oxymeter tipe SO911 yang diletakkan pada penjepit jari. Hasil pengukuran sensor MAX30100 akan tertampil pada layar OLED, begitu juga pengukuran dengan oxymeter akan tertampil pada OLED pada alat pembanding. Hasil pembacaan sensor dan alat oxymeter dicatat pada tabel.

TABEL 3.

HASIL PENGUJIAN HEAT RATE SENSOR MAX30100 SEBELUM KALIBRASI DENGAN OXYMETER SO911

\begin{tabular}{|c|c|c|c|c|c|}
\hline \multirow[b]{2}{*}{ No } & \multirow[b]{2}{*}{ Nama } & \multicolumn{2}{|c|}{ Perbandingan sensor } & \multirow[b]{2}{*}{$\begin{array}{c}\text { Error } \\
\text { (BPM) }\end{array}$} & \multirow[b]{2}{*}{$\begin{array}{c}\text { Relative } \\
\text { Error } \\
(\%)\end{array}$} \\
\hline & & $\begin{array}{c}\text { Oxymeter } \\
\text { SO911 } \\
\text { (BPM) } \\
\end{array}$ & $\begin{array}{c}\text { MAX30100 } \\
\text { (BPM) }\end{array}$ & & \\
\hline 1 & Sholihin & 92 & 89,22 & 2,78 & 3,021 \\
\hline 2 & Adri & 86 & 83,12 & 2,88 & 3,348 \\
\hline 3 & Amin & 87 & 86,65 & 0,35 & 0,402 \\
\hline 4 & Ilman & 88 & 86,9 & 1,1 & 1,125 \\
\hline 5 & Fatih & 85 & 82,7 & 2,3 & 2,705 \\
\hline \multicolumn{4}{|c|}{ Rata - rata error dan relative error } & 1,882 & 2,145 \\
\hline
\end{tabular}

TABEL 4.

HASIL PENGUJIAN SPO2 SENSOR MAX30100 SEBELUM KALIBRASI DENGAN OXYMETER SO911

\begin{tabular}{|c|c|c|c|c|c|}
\hline \multirow[b]{2}{*}{ No } & \multirow[b]{2}{*}{ Nama } & \multicolumn{2}{|c|}{ Perbandingan sensor } & \multirow[b]{2}{*}{$\begin{array}{c}\text { Error } \\
(\%)\end{array}$} & \multirow{2}{*}{$\begin{array}{c}\text { Relative } \\
\text { Error } \\
(\%)\end{array}$} \\
\hline & & $\begin{array}{c}\text { Oximeter } \\
\text { S0911 (\%) }\end{array}$ & $\begin{array}{c}\text { MAX30100 } \\
(\%) \\
\end{array}$ & & \\
\hline 1 & Sholihin & 98 & 96 & 2 & 2,040 \\
\hline 2 & Adri & 96 & 95 & 1 & 1,041 \\
\hline 3 & Amin & 97 & 95 & 2 & 2,061 \\
\hline 4 & Ilman & 96 & 95 & 1 & 1,041 \\
\hline 5 & Fatih & 96 & 95 & 1 & 1,041 \\
\hline & Rata - rat & ror dan rela & error & 1,4 & 1,445 \\
\hline
\end{tabular}

Berdasarkan tabel 3 dan tabel 4 sensor MAX30100 yang digunakan untuk memonitoring detak jantung dan saturasi oksigen dalam darah pasien telah berfungsi dengan baik akan tetapi kesalahan tingkat akurasi pengukuran sensor masih tinggi dibandingkan dengan standar alat ukur komersial, dari hasil pengujian pada sensor MAX30100 dapat diketahui bahwa nilai $\mathrm{SpO} 2$ cenderung lebih akurat dibandingkan dengan nilai heart rate. Hasil pengukuran tinggkat rata-rata error pada heart rate sebesar 1,882 BPM yang berarti tingkat akurasi pengukuran heart rate pada sensor kurang akurat dibandingkan dengan hasil standar dari oxymeter komersial. Sedangkan hasil pengukuran tingkat rata-rata error pada $\mathrm{SpO} 2$ sebesar 1,4\% yang berarti tingkat akurasi pengukuran sensor ketika dibandingkan dengan oxymeter komersial tidak terpaut jauh, sehingga sensor MAX30100 ini dalam mengukur SpO2 cukup baik. Akan tetapi untuk mendapatkan hasil akurasi yang bagus perlu dilakukan kalibrasi dan perbaikan ulang pada hardware maupun software sensor tersebut.
TABEL 5.

HASIL PENGUJIAN HEAT RATE SENSOR MAX30100 SETELAH KALIBRASI DENGAN OXYMETER SO911

\begin{tabular}{cccccc}
\multicolumn{5}{c}{ DENGAN OXYMETER SO911 } \\
\hline
\end{tabular}

TABEL 6.

HASIL PENGUJIAN SPO2 SENSOR MAX30100 SETELAH KALIBRASI DENGAN

\begin{tabular}{|c|c|c|c|c|c|}
\hline & & \multicolumn{2}{|c|}{ OXYMETER SO911 } & \multirow[b]{3}{*}{$\begin{array}{c}\text { Error } \\
(\%)\end{array}$} & \multirow{3}{*}{$\begin{array}{c}\text { Relative } \\
\text { Error } \\
(\%)\end{array}$} \\
\hline \multirow[b]{2}{*}{ No } & \multirow[b]{2}{*}{ Nama } & Perband & an sensor & & \\
\hline & & $\begin{array}{c}\text { Oxymeter } \\
\text { SO911 (\%) } \\
\end{array}$ & $\begin{array}{c}\text { MAX30100 } \\
(\%)\end{array}$ & & \\
\hline 1 & Sholihin & 98 & 97 & 1 & 1,020 \\
\hline 2 & Adri & 96 & 96 & 0 & 0 \\
\hline 3 & Amin & 97 & 96 & 1 & 1,030 \\
\hline 4 & Ilman & 96 & 96 & 0 & 0 \\
\hline 5 & Fatih & 96 & 95 & 1 & 1,041 \\
\hline \multicolumn{4}{|c|}{ Rata - rata error dan relative error } & 0,6 & 0,618 \\
\hline
\end{tabular}

Dari tabel 5 dan tabel 6 diatas menunjukkan bahwa dengan mengkalibrasi sensor MAX30100 tingkat akurasi sensor jauh lebih baik dari sebelumya, pada pengujian setelah dikalibrasi diperoleh nilai rata-rata error pada pengukuran heart rate sebesar 0.52 BPM, sedangkan pada pengukuran $\mathrm{SpO} 2$ diperoleh nilai rata-rata error sebesar $0,6 \%$. Hasil pengujian ditampilkan pada grafik diagram batang berikut:

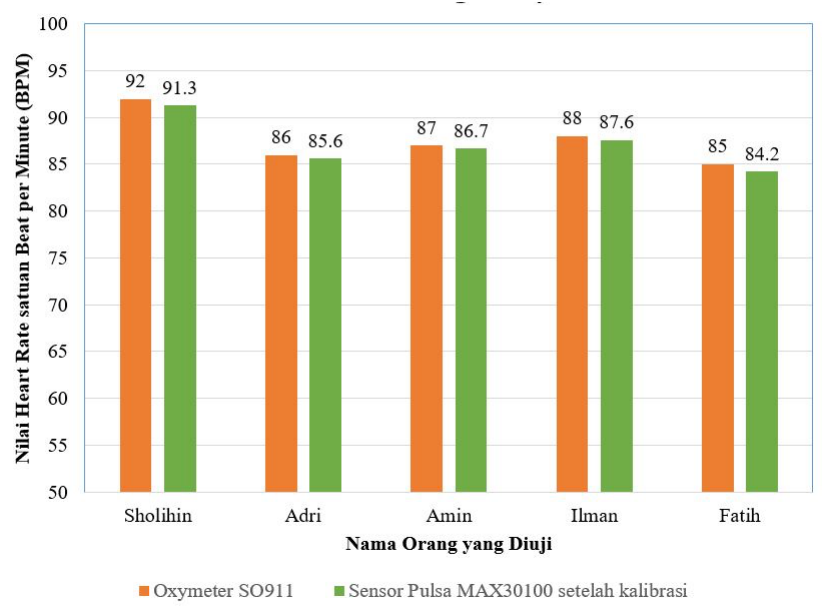

Gambar 5. Grafik perbandingan pengujian heart rate menggunakan sensor MAX30100 dengan Oxymeter SO911 


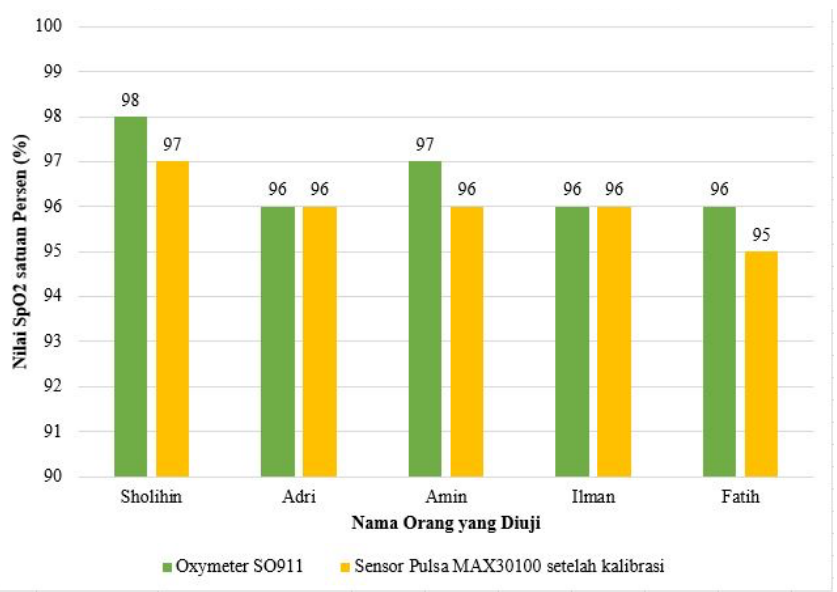

Gambar 6. Grafik perbandingan pengujian $\mathrm{SpO} 2$ menggunakan sensor MAX30100 dengan Oxymeter SO911

Dari gambar 5 dan 6 dapat dilihat hasil grafik perbandingan pengujian sensor MAX30100 dengan oxymeter kemersial tipe SO911 menunjukkan perbedaan heart rate maupun $\mathrm{SpO} 2$ yang tidak terlalu signifikan dan mendekati nilai sebenarnya pada pengukuran MAX30100 yang sudah dikalibrasi.

Pada salah satu sampel pasien bernama Adri merupakan sampel dengan nilai error heart rate paling besar diantara sampel lain, menunjukkan pengukuran dengan oxymeter komersial mendapatkan hasil sebesar 86 BPM sedangkan pada sensor MAX30100 sebelum dikalibrasi menunjukkan hasil pengukuran 83,12 BPM, hasil tersebut memiliki selisih error sebesar 2,88 BPM. Namun setelah melakukan kalibrasi dan dilakukan pengukuran kembali mendapatkan hasil 85,6 BPM dengan selisih error 0,4 BPM, kemudian pada pengujian $\mathrm{SpO} 2$ pada sampel pasien tersebut didapatkan hasil 96\% pada pengukuran menggunakan oxymeter komersial tipe SO911, sedangkan pengujian menggunakan sensor MAX30100 diperoleh nilai 95\% sebelum kalibrasi, hasil tersebut memiliki selisih error sebesar $1 \%$ dari hasil pengukuran dengan oxymeter komersial. Setelah sensor MAX30100 dikalibrasi dan dilakukan pengujian ulang didapatkan nilai sebesar 96\%, hasil pengukuran $\mathrm{SpO} 2$ sensor pada sampel pasien Adri sudah menunjukan nilai sama dengan hasil pengukuran oxymeter komersial. Dari kedua hasil pengukuran sensor MAX30100 setelah dilakukan dikalibrasi hardware maupun software menunjukkan tingkat akurasi yang sangat baik yaitu $99,407 \%$ untuk keakuratan dalam parameter detak jantung dan 99,382\% untuk parameter $\mathrm{SpO} 2$.

\section{Pengujian kualitas layanan}

Pengujian kualitas layanan atau disebut juga Quality of Service (QoS) bertujuan untuk mengetahui bagaimana kemampuan sebuah jaringan dengan melakukan pengukuran beberapa parameter QoS yaitu Throughput, Packet loss, Delay, dan Jitter dengan menggunakan aplikasi Wireshark.
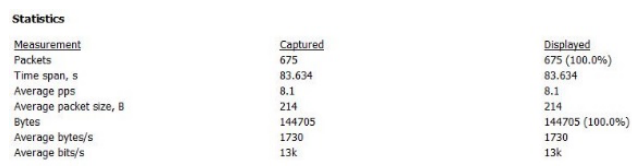

Gambar 13. Tampilan Statistik pada wireshark

\section{Pengujian Throughput}

Throughput merupakan jumlah total kedatangan paket sukses yang diamati selama interval tertentu dibagi oleh durasi interval waktu tersebut. Throughput merupakan kemampuan suatu jaringan dalam mentransfer data efektif yang diukur dalam bps (bit per second).

TABEL 7.

KATEGORI THROUGHPUT

\begin{tabular}{ccc}
\hline Kategori & Throughput (Kbps) & Indeks \\
\hline Sangat Bagus & $>2100$ & 4 \\
Bagus & $1200-2100$ & 3 \\
Sedang & $700-1200$ & 2 \\
Kurang baik & $338-700$ & 1 \\
Buruk & $0-338$ & 0 \\
\hline
\end{tabular}

Perhitungan Throughput:

Throughput $=\frac{\text { Paket data diterima }}{\text { Lama pengamatan }}$

Throughput $=\frac{\text { Jumlah Bytes }}{\text { Time span }}$

Throughput $=\frac{144705 \text { Bytes }}{83,634 \mathrm{~s}}=1730$ Bytes $/ \mathrm{s}$

Throughput $=1730$ Bytes $/ \mathrm{s} \times 8$ bit $=13840 \mathrm{bps}$

Throughput $=13,840 \mathrm{Kbps}$

Dari hasil perhitungan diperoleh kecepatan pengiriman data sebesar 1730 Bytes/s. Menurut standarisasi ETSI menggunakan satuan bps (bit per second) sehingga perlu diubah terlebih dahulu. Maka diperoleh nilai Throughput sbesar 13,840 Kbps. Hasil tersebut menurut standar TIPHON termasuk kategori buruk, karena data yang dikirim kecil sehingga memengaruhi nilai throughput.

\section{Pengujian Packet Loss}

Packet loss merupakan suatu kegagalan transmisi paket dalam mencapai tujuannya. Kegagalan tersebut bisa disebabkan oleh beberapa kemungkinan seperti overload traffic dalam jaringan, tabrakan dalam jaringan, dan kegagalan pada sisi penerima.

TABEL 8.

\begin{tabular}{ccc}
\multicolumn{3}{c}{ KATEGORI PACKET LOSS } \\
\hline Kategori & Packet Loss (\%) & Indeks \\
\hline Sangat Bagus & $0-2$ & 4 \\
Bagus & $3-14$ & 3 \\
Sedang & $15-24$ & 2 \\
Jelek & $>25$ & 1 \\
\hline
\end{tabular}

Perhitungan Packet Loss:

$$
\begin{aligned}
\text { Packet Loss }= & \frac{(\text { Paket data dikirim }- \text { paket data diterima })}{\text { paket data dikirim }} \\
\text { Packet Loss }= & \frac{(675-675)}{675} \times 100 \%=0 \%
\end{aligned}
$$

Dari hasil perhitungan didapatkan nilai packet loss adalah $0 \%$. Menurut standar ETSI nilai packet loss $0 \%$ termasuk dalam kategori sangat bagus. Hal ini disebabkan data yang terkirim semuanya diterima dengan baik tanpa ada gangguan.

\section{Pengujian Delay}

Delay merupakan waktu tunda suatu data yang diakibatkan oleh proses transmisi dari titik asal menuju tujuannya. Delay dipengaruhi oleh jarak, media fisik, 
congesti maupun proses yang memerlukan waktu cukup lama.

TABEL 9.

KATEGORI DELAY

\begin{tabular}{ccc}
\multicolumn{3}{c}{ KATEGORI DELAY } \\
\hline Kategori & Delay (ms) & Indeks \\
\hline Sangat Bagus & $<150$ & 4 \\
Bagus & $150-300$ & 3 \\
Sedang & $300-450$ & 2 \\
Jelek & $>450$ & 1 \\
\hline
\end{tabular}

Perhitungan total delay:

Total Delay $=$ jumlah seluruh delay perpaket

Total Delay $=83,634292 \mathrm{~s}$

Perhitungan rata-rata delay:

$$
\begin{aligned}
\text { Rata }- \text { rata delay } & =\frac{\text { total delay }}{\text { total paket diterima }} \\
\text { Rata }- \text { rata delay } & =\frac{83,634292 \mathrm{~s}}{674}=0,12408649 \mathrm{~s} \\
& =124,08649 \mathrm{~ms}
\end{aligned}
$$

Dari hasil perhitungan delay diperoleh nilai rata-rata delay sebesar $124,08649 \mathrm{~ms}$. Menurut standar ETSI nilai terebut termasuk kategori sangat bagus karena nilai kurang dari 150 ms. Hal ini dikarenakan waktu yang diperlukan suatu untuk diterima oleh tujuan tidak ada gangguan dan diterima dengan sangat bagus.

\section{Pengujian Jitter}

Jitter merupakan variasi dari delay antar paket yang terjadi pada jaringan. Apabila variasi delay dalam transmisi terlalu lebar, maka akan memengaruhi kualitas data yang ditransmisikan. Besarnya nilai jitter akan sangat dipengaruhi oleh variasi beban trafik dan besarnya tabrakan antar paket yang ada dalam jaringan.

TABEL 10

\begin{tabular}{ccc}
\multicolumn{3}{c}{ TABEL 10. } \\
KATEGORI JITTER \\
\hline Kategori & Jitter (ms) & Indeks \\
\hline Sangat Bagus & 0 & 4 \\
Bagus & $0-75$ & 3 \\
Sedang & $75-125$ & 2 \\
Jelek & $125-225$ & 1
\end{tabular}

$$
\begin{aligned}
& \text { Adapun cara menghitung Jitter yaitu: } \\
& \text { Total variasi delay }=((\text { delay } 2-\text { delay } 1) \\
& +(\text { delay } 3-\text { delay } 2)+\cdots \\
& +(\text { delay } n-\operatorname{delay}(n-1)) \\
& \text { Total variasi delay }=109,324 \mathrm{~s} \\
& \text { Jitter }=\frac{\text { total variasi delay }}{\text { total paket diterima }} \\
& \text { Jitter }=\frac{109,324 \mathrm{~s}}{674}=0,1622 \mathrm{~s}=162,2 \mathrm{~ms}
\end{aligned}
$$

Dari hasil perhitungan jitter diperoleh nilai jitter sebesar 162,2 ms. Menurut standar ETSI hasil tersebut termasuk dalam kategori Jelek karena masuk pada rentang $125 \mathrm{~ms}$ sampai $225 \mathrm{~ms}$. Hal ini disebabkan karena variasi delay dalam panjang antrian dan waktu pengolahan paket data yang tinggi, sehingga peluang terjadinya tumbukan antar paket tinggi menyebabkan nilai jitternya besar.

\section{KESIMPULAN}

Sensor suhu MLX90614 menunjukkan keakuratan sensor mencapai 99,673\%, dan sensor MAX30100 dengan akurasi sensor $99,407 \%$ dalam mengukur detak jantung serta keakuratan sensor sebesar 99,382\% dalam pengukuran kadar oksigen dalam darah. Pada pengujian Quality of Service (QoS) memperoleh nilai throughput sebesar 13,840 Kbps, packet loss $0 \%$, rata-rata delay $124,08649 \mathrm{~ms}$ dan jitter 162,2 ms.

\section{REFERENSI}

[1] A. Yurianto, "PEDOMAN PENCEGAHAN DAN PENGENDALIAN CORONAVIRUS DISEASE (COVID-19)," 27 Maret 2020. [Online]. Available: https://infeksiemerging.kemkes.go.id/download/REV04_Pedoman_P2_COVID-

19_27_Maret2020_TTD1.pdf. [Använd 23 Desember 2020].

[2] R. H. Yoga Perdana, N. Hidayati, A. W. Yulianto, V. Al Hadid Firdaus, N. N. Sari and D. Suprianto, "Jig Detection Using Scanning Method Base On Internet Of Things For Smart Learning Factory," 2020 IEEE International IOT, Electronics and Mechatronics Conference (IEMTRONICS), 2020, pp. 1-5.

[3] A. Nurbaeti, M. Kusumawardani, and H. Darmono, "Design and Build a Coffee Bean Dryer Based on Internet Of Things", Jurnal Jaringan Telekomunikasi, vol. 11, no. 2, pp. 74-80, Jun. 2021.

[4] A. Zamahuri, "Automatic Control System for Swallow's Nest Cultivation Using the Internet of Things", Jurnal Jaringan Telekomunikasi, vol. 9, no. 4, pp. 8-12, Dec. 2019.

[5] Taufik, M., Hudiono, H., Rakhmania, A. E., Perdana, R. H. Y., \& Sari, A. S. (2021). An Internet of Things Based Intercity Bus Management System for Smart City. International Journal of Computing and Digital Systems, 10.

[6] R. H. Y. Perdana, Hudiono, M. Taufik, A. E. Rakhmania, R. M. Akbar, and Z. Arifin, "Hospital queue control system using Quick Response Code (QR Code) as verification of patient's arrival," Int. J. Adv. Comput. Sci. Appl., vol. 10, no. 8, 2019.

[7] A. Saidah, "Design of Prototype System for Temperature and Humidity Control in Flour Storage", Jurnal Jaringan Telekomunikasi, vol. 5, no. 2, pp. 59-64, Nov. 2017.

[8] H. Hudiono, M. Taufik, R. H. Y. Perdana, and W. R. Rohmah, "Design and implementation of centralized reading system on analog postpaid water meter," in IOP Conference Series: Materials Science and Engineering, 2020, vol. 732, no. 1 . 